\title{
Does an Investment Treaty Tribunal Need Special Consent for Mass Claims?
}

\author{
Berk Demirkol
}

\begin{abstract}
Abaclat $v$ Argentina, the first case in the history of investment arbitration where an investment treaty tribunal dealt with a mass claim (a claim initiated by numerous claimants), stimulated many debates even before the tribunal rendered its decision on jurisdiction and admissibility. This article focuses on only one of the matters on which the case triggered discussion, though probably the most important: whether or not an investment treaty tribunal needs special consent for mass claims. The views of the parties and of the majority and dissenting arbitrators in both Abaclat and Ambiente Ufficio diverged as to whether or not special consent is required for mass claims. The discussion rests mainly upon the qualification of mass claims in investment arbitration and their distinction from class arbitration, traditional mass claims processes and other multi-party proceedings. The article explores the merits of the arguments of both camps to determine which gives a more convincing answer to the question.
\end{abstract}

\section{Keywords}

Investment arbitration, jurisdiction and admissibility, special consent, mass claims, class arbitration, multi-party proceedings

\footnotetext{
PhD candidate, University of Cambridge. I owe special thanks to my friend, Mr Michail Dekastros, who gave very valuable advice during all the stages of the preparation of this article. I am also very grateful to Prof S I Strong, who kindly gave her opinions on a previous draft of this piece and whose comments were very useful; and to my friends, Aslı Güner and Simon Paul, for reading a previous draft and giving their helpful thoughts.
} 


\section{Introduction}

It has been almost thirty years since the filing of the first investment arbitration claim based on a unilateral promise to arbitrate which is not incorporated in a contract, but in a national law or an international treaty concerning investment protection. ${ }^{1}$ Investment arbitration based on an instrument containing a unilateral offer by one or more host states to arbitrate any investment dispute with any qualifying investor carried international investment law into a new era: 'arbitration without privity.'

An unexpected yet natural development that follows from the availability of arbitration without privity is that a group of investors who are deprived of their rights against the same factual background can initiate an investment claim collectively, so long as each individual claimant satisfies the jurisdictional conditions under the investment treaty and, if applicable, under the 1965 Convention on the Settlement of Investment Dispute Between States and Nationals of Other States (ICSID Convention). Apart from investment claims initiated together by companies from the same group or partners in the same investment, the first collective claim before the International Centre for Settlement of Investment Disputes (ICSID or the Centre) initiated by multiple investors who were in the same situation but who had made separate investments was Bernardus Henricus Funnekotter and Others $v$ Republic of Zimbabwe. ${ }^{3}$ An investment treaty claim initiated by slightly more than a dozen investors, who were owners of different farms, did not create a problem in Funnekotter. The plurality of independent investors was not raised as a jurisdictional objection by the respondent, nor did the tribunal consider this issue an obstacle to its jurisdiction. ${ }^{4}$

The scale of the Abaclat and Others v Argentine Republic case was, however, not comparable. ${ }^{5}$ In Abaclat, the total number of claimants at the time of the initiation of the arbitration exceeded 180,000 . It is not coincidental that so many

1 SPP v Egypt, ICSID Case No ARB/84/3 (Decision on Jurisdiction, 27 November 1985) (unilateral promise in an investment promotion law) and Asian Agricultural Products $v$ Sri Lanka, ICSID Case No ARB/87/3 (Award, 27 July 1990) (UK-Sri Lanka BIT) are the first examples of their kind. For further examples, see C Schreuer et al, The ICSID Convention: A Commentary (2nd edn, 2009) 196, 205.

2 J Paulsson, 'Arbitration Without Privity' (1995) 10 ICSID Rev/FILJ 232.

3 Bernardus Henricus Funnekotter and Others v Republic of Zimbabwe, ICSID Case No ARB/05/6 (Award, 22 April 2009).

${ }^{4}$ See ibid, paras $91-5$.

5 Abaclat and Others (Case formerly known as Giovanna a Beccara and Others) v Argentine Republic, ICSID Case No ARB/07/5 (Decision on Jurisdiction and Admissibility, 4 August 2011). 
investors that were independent of each other were affected by the same facts and filed a single case. Putting to one side discussions of what might constitute an investment, ${ }^{6}$ there might be many situations where investors, especially smalland medium-sized, suffer from the same act of the host state and are in the same situation. One recent example may be the imposition of a levy on bank deposits in Cyprus. Another example may be the hypothetical situation where a host state denies the rights of the shareholders of a listed company during a liquidation process. In these cases, many individual investors are affected by the same wrongful act of the state. It is important to note that not all of these investors would be able to afford the legal fees and tribunal expenses if they filed investment claims individually. Waibel has thus argued that the method of mass claims is an effective option in respect of bondholders' claims in a case of default by the issuer state. $^{7}$

Whereas the majority in the Abaclat tribunal upheld the use of mass claims in investment arbitration for this purpose, Georges Abi-Saab, the dissenting arbitrator, opposed it, maintaining that the silence of the rules on this issue may not be interpreted such that parties automatically consent to multi-party arbitration. The dissenting arbitrator required parties' special consent to a mass claim action (which he calls 'secondary consent'). ${ }^{8}$ He based his opinion on United States class arbitration procedures and on mass claim mechanisms in international law. ${ }^{9}$

The unforeseeability of mass claims at the time of the conclusion of the ICSID Convention and investment treaties has also been much discussed in relation to Abaclat. This argument has been relied on as a hurdle to be overcome before a tribunal can hear such a case. ${ }^{10}$ In the second Argentine bond case, the arbitral tribunal answered this argument by reference to the relevant bilateral investment treaty (BIT):

[T] he authors of the BIT by the very act of including [the bonds] into the list of protected investments, were envisaging a high number of potential claimants. The Tribunal cannot see why in constellations

\footnotetext{
${ }^{6}$ Most recently on this issue, see M Dekastros, 'Portfolio Investment: Reconceptualising the Notion of Investment under the ICSID Convention' (2013) 14 JWIT 286. See also C Lévesque, 'Case Comment: Abaclat and Others v Argentine Republic: The Definition of Investment' (2012) 27(2) ICSID Rev/FILJ 247.

7 M Waibel, Sovereign Defaults before International Courts and Tribunals (2011) 277.

${ }^{8}$ Abaclat (Abi-Saab, diss, 28 October 2011), para 175.

9 Ibid, para 190.

${ }^{10}$ Ibid, para 165; S Manciaux, 'Chronique des sentences arbitrales' (2012) 139 JDI 'Clunet' 263, 309.
} 
involving mass instruments such as bonds several claimants finding themselves in an analogous situation should not be allowed to bring their claims together before one arbitral tribunal. Thus, multi-party proceedings appear to be a particularly typical course of action when the collective nature of the proceedings derives from the nature of the investment made. ${ }^{11}$

Reference should also be made to the Permanent Court of International Justice, which stated in the Employment of Women During the Night case:

The mere fact that, at the time when the Convention on Night Work of Women was concluded, certain facts or situations, which the terms of the Convention in their ordinary meaning are wide enough to cover, were not thought of, does not justify interpreting those of its provisions which are general in scope otherwise than in accordance with their terms. ${ }^{12}$

The question whether the ordinary meaning of the ICSID Convention covers mass claims constitutes the core of the subject of this article. The article does not seek, however, to engage in an interpretative task in the framework of the Vienna Convention on the Law of the Treaties as regards the conditions embedded in Article 25 of the ICSID Convention. Instead it will discuss a rather more practical question. The problematic of this article is whether additional and specific consent is required to file mass claims in investment treaty arbitration. A thorough analysis must have several aspects. The first aspect this article will discuss is the legal characterisation and significance of this type of claim (section 2 of the article). The second is the determination of the kind of preliminary objection (jurisdiction or admissibility) to which the mass element of a claim relates (3). The article will then analyse whether reference to or analogy with class arbitration (4) or international mass claims processes (5) provides an adequate framework for understanding mass investment claims. Finally, it will examine whether mass claims dispose of any of the situations where additional consent is required in the framework of multi-party proceedings (6).

${ }_{11}$ Ambiente Ufficio SpA and Others (Case formerly known as Giordano Alpi and Others) v Argentine Republic, ICSID Case No ARB/08/9 (Decision on Jurisdiction and Admissibility, 8 February 2013) para 144.

${ }^{12}$ Interpretation of Convention of 1919 concerning Employment of Women during the Night, PCIJ Ser A/B No 50, Advisory Opinion, 377. Cf the analysis of Van Houtte and McAsey, who quote the same passage: H van Houtte \& B McAsey, 'Case Comment: Abaclat and others v Argentine Republic: ICSID, the BIT and Mass Claims' (2012) 27 ICSID Rev/FILJ 231, 233. 


\section{Characterisation and significance of mass (investment) claims}

It is preferable to use the term 'mass claims' to describe the type of claim initiated in Abaclat. Sometimes they will be referred to in this article as 'Abaclat-type mass claims': claims where the claimants are independent from each other (there is no legal connection between the claimants, but instead the connecting factor is the background to their claims) and the number of claimants is so big that it is almost impossible to analyse each claimant's characteristics and claim separately, or to examine them individually. One might describe this type of claim as 'collective relief' as well. ${ }^{13}$ But 'mass claim', as used in this article to describe Abaclat-type claims, is not a technical term; ${ }^{14}$ it is a factual qualification of the situation in the Abaclat case.

A careful eye can distinguish this case from other multi-party investment claims, including Ambiente Ufficio, Funnekotter and three non-ICSID collective cases. ${ }^{15}$ Wheras the Abaclat case was initially filed by 180,000 claimants (at the time of the issuance of the decision on jurisdiction and admissibility, there were still 60,000 claimants), ${ }^{16}$ those other investment cases did not involve more than a couple of dozen claimants. Even in one of the most 'crowded' cases among them, the tribunal insisted that there would not be any implications arising from the

\footnotetext{
${ }^{13}$ See S I Strong, 'From Class to Collective: The De-Americanization of Class Arbitration' (2010) 26 Arb Int 493, 495. On the other hand, the author qualifies the Yukos cases as a 'mass arbitration'. In the sense used in this article, the terms 'mass claim' and 'mass arbitration' could not be applied here, i.e. to a small number of parallel proceedings that are initiated separately by a single claimant each time but that involve a large dispute relating to one investor. See Hulley Enterprises Limited (Cyprus) $v$ Russian Federation, PCA Case No AA 226, UNCITRAL; Yukos Universal Limited (Isle of Man) v Russian Federation, PCA Case No.AA 227, UNCITRAL; Veteran Petroleum Limited (Cyprus) $v$ Russian Federation, PCA Case No AA 228, UNCITRAL.

${ }^{14}$ See Ambiente Ufficio, above n 11, para 119.

${ }^{15}$ The three non-ICSID cases are: Bayview Irrigation District et al $v$ United Mexican States, ICSID Case No ARB(AF)/05/1 (Award, 19 June 2007) (46 claimants); Alasdair Ross Anderson et al v Republic of Costa Rica, ICSID Case No ARB(AF)/07/3 (Award, 19 May 2010) (137 claimants); Canadian Cattlemen for Fair Trade $v$ United States of America, NAFTA/UNCITRAL (Award on Jurisdiction, 28 January 2008) (109 claimants). In none of these cases did the respondent state make or the tribunal deal with an objection to jurisdiction due to a collective claim being initiated by numerous claimants. In fact, in Cattlemen the parties, after issuing 109 separate requests for arbitration, agreed to the consolidation of the claims before a single tribunal. The situation is consequently quite different: Cattlemen (Award on Jurisdiction, 28 January 2008) para 6. In the other two cases, parties submitted a single request for arbitration: Bayview (Award, 19 June 2007) para 1; Anderson (Award, 19 May 2010) para 2.

${ }^{16}$ Abaclat, above n 5, para 294.
} 
number of claimants (initially 119, and at the time of the issuance of the decision on jurisdiction and admissibility 90), ${ }^{17}$ while the tribunals in the other four cases did not even consider this issue.

The significance of the fact that an investment claim is a mass claim lies particularly within the modifications or adaptations of the procedural rules that are required in order to ensure the case is manageable. These modifications or adaptations might violate due process rights, or at least the procedural guarantees that the respondent legitimately expects. The problem does not consist in a mere technical difference between responding to a single claimant and to a large number of claimants; more importantly, it resides in the implications for the procedural guarantees of the respondent of having a large number of opposing parties. Consent to mass claims, if one concludes that it is necessary, will thus entail a waiver of the right to object to the necessary procedural adaptations.

This article will therefore discuss the legitimacy of concerns arising from the implications of the very large number of claimants within the framework of the Abaclat case. A different outcome might be reached from that in the five cases mentioned in this section. The mere fact that a simple chart showing only the names, addresses and investments of each claimant might take around 10,000 pages might illustrate why the case is different from others. Procedural concerns that mass claims might generate in investment arbitration will be treated in greater detail in section 6 . The questions of whether investment mass claims are technically class arbitrations and whether they share common features with mass proceedings in international law will also be left to later sections (4 and 5).

It will follow from the conclusions of the subsequent sections that an investment mass claim, such as Abaclat, is neither a class arbitration, nor a mechanism similar to mass proceedings in international law. What is called factually a 'mass claim' in this article is technically a multi-party arbitration. ${ }^{18}$ But qualifying such an arbitration as a 'multi-party arbitration' is not helpful. There are many methods, such as consolidation or joinder, that lead to a multi-party arbitration. A 'mass claim' is not comparable to those procedures. Even if it is not a technical term, therefore, the factual description 'mass claim' will be used to refer to the type of arbitration in Abaclat in order to distinguish it from other available procedures in international and municipal law.

\footnotetext{
${ }_{17}$ Ambiente Ufficio, above n 11, para 120.

${ }^{18}$ Ibid, para 122.
} 


\section{Mass claims: a problem of jurisdiction or admissibility?}

One of the fundamental disagreements between the majority and the dissenting arbitrator in the Abaclat tribunal was whether initiating a mass claim concerns the jurisdiction of the tribunal or the admissibility of the claim. The majority dissociated from the jurisdiction of the tribunal issues such as the compatibility of the mass aspect of the claims with ICSID arbitration and arbitral tribunals' power over procedural adaptations. ${ }^{19}$ The majority highlighted that even if the claim were inadmissible due to the mass aspect of the claim, the reason for this outcome would not be the lack of consent to mass claims, but the inability of tribunals to deal with mass claims under the ICSID regime. ${ }^{20}$ On the other hand, the dissenting arbitrator considered the mass aspect of the claim within the ambit of the jurisdiction of the tribunal. ${ }^{21}$ He stated that any limits to the legal power to exercise the judicial or arbitral function (the arbitrator refers implicitly to the limits envisaged in the procedural rules) were jurisdictional. ${ }^{22}$

The jurisdiction of the Centre is provided for in Articles 25-27 of the ICSID Convention. Article 25 reads in part: '[t]he jurisdiction of the Centre shall extend to any legal dispute arising directly out of an investment, between a Contracting State [...] and a national of another Contracting State, which the parties to the dispute consent in writing to submit to the Centre'. Accordingly, jurisdiction is established in respect of the legal dispute (ratione materiae), the nationality of the investors (ratione personae), and the consent given by the parties. The number of investors involved in a case concerns neither the characteristics of a legal dispute, nor the investors' nationality.

Furthermore, Article 44 of the ICSID Convention, under 'Section 3: Powers and Functions of the Tribunal', reads in part: '[a]ny arbitration proceeding shall be conducted [...], except as the parties otherwise agree, in accordance with the Arbitration Rules in effect on the date on which the parties consented to arbitration'. The mass aspect of an investment claim is certainly covered by this article: the solution depends on its interpretation. That is also why even the dissenting arbitrator referred extensively to Article 44 and Rule 19 of the Arbitration Rules. ${ }^{23}$ It seems that the dissenting arbitrator confused the binding

\footnotetext{
${ }^{19}$ Abaclat, above n 5, paras 491-2.

${ }^{20}$ Ibid, para 491.

${ }^{21}$ Abaclat (Abi-Saab, diss, 28 October 2011), paras 126-7.

22 Ibid, para 126.

${ }^{23}$ See ibid, paras 194-262.
} 
character of procedural rules and the inherent powers of a tribunal with the jurisdiction of the Centre.

Even the grounds for the annulment of a tribunal's award would be different in these two cases. Article 52(1) of the ICSID Convention distinguishes them clearly. To be more precise, the Convention provides for a specific annulment ground in case an ICSID tribunal breaches the procedural rights of a party. While the absence of consent would be a ground to apply Article 52(1)(b), which concerns the manifest excess of a tribunal's power, if the tribunal disrespects a party's procedural rights it might also be able to invoke the more specific annulment ground in Article 52(1)(d), which applies where 'there has been a serious departure from a fundamental rule of procedure. ${ }^{24}$

Poudret and Besson recognise that joining parties that have signed identical arbitration clauses in the same arbitral proceedings is governed by the rules governing the conduct of the arbitral procedure, particularly with regard to the existence of a sufficient degree of connexity, and does not depend on the arbitration agreements themselves, given that their identity ensures the respect of their terms. ${ }^{25}$ This passage suggests that even in international commercial arbitration the joining of claims is a procedural matter and not a jurisdictional one (in that the issue is not related to the consent of the parties).

In fact, parties' agreement on procedural issues falls within the scope of Article 44 and not Articles 25-27. In other words, consent to arbitrate a legal dispute and the jurisdiction of a tribunal do not cover issues such as how a tribunal would exercise its power and how it would control procedural matters in a specific case. ${ }^{26}$ Indeed, the existence of consent to arbitrate a legal dispute is a different question from whether a particular case can be arbitrated pursuant to existing procedural rules. While the former is a jurisdictional issue, the latter is about the admissibility of the claim.

Unfortunately, most of the cases in international courts and tribunals that deal with both jurisdictional objections and objections related to the admissibility of the claim have not brought forth useful clarification or a consistent approach to why and when an issue should be treated as one rather than the other. ${ }^{27}$ The

\footnotetext{
${ }^{24}$ See Schreuer, above n 1, 938, 980.

${ }^{25}$ J F Poudret \& S Besson, Comparative Law of International Arbitration (2nd edn, 2007) 198-9.

${ }^{26}$ Cf S Rosenne, The Law and Practice of the International Court (1920-2005), vol II (2006) 584.

${ }^{27}$ See also I A Laird, 'A Distinction without a Difference? An Examination of the Concepts of Admissibility and Jurisdiction in Salini v. Jordan and Methanex v. USA', in T Weiler (ed), International Investment Law and Arbitration: Leading Cases from the ICSID, NAFTA, Bilateral Treaties and Customary International Law (2005) 201, 201.
} 
nature of preliminary objections based on the admissibility of the claim has been best described by Douglas:

The grounds of inadmissibility at base represent certain legal defects in a claim that are independent of, and yet often closely connected to, the substantive grounds upon which a claim or counter-claim is to be adjudicated on the merits. Admissibility deals with the suitability of the claim for adjudication on the merits. ${ }^{28}$

The Hochtief tribunal, though it took a different approach from Douglas, reached a similar outcome in connection with the admissibility of a claim, noting that " tribunal] might refuse even to receive and become seised of a claim that is within its jurisdiction because of some fundamental defect in the manner in which the claim is put forward. ${ }^{29}$ A procedural defect, if there is a defect in bringing a mass claim, is hence related to the admissibility of the claim and not to the jurisdiction of the tribunal. The correct approach in Abaclat should therefore have been to find out whether the tribunal would be able to 'handle' the claim under the existing procedural rules and powers attributed to an ICSID tribunal without violating the procedural rights of the parties. ${ }^{30}$

Notwithstanding this, the dissenting arbitrator in Abaclat, instead of splitting the preliminary objections into two groups-jurisdiction and admissibility-was of the opinion that each issue constituted a different layer of consent. ${ }^{31}$ The dissenting arbitrator took the idea of different layers of consent from Strong. According to Strong, the first layer is the consent to arbitrate the dispute; the second layer is the consent for a mass claim. To this, the dissenting arbitrator added a third layer, namely the consent to procedural rules. ${ }^{32}$ Whether or not this is called 'special consent', 'secondary consent' or just an admissibility problem, it is

\footnotetext{
${ }^{28} \mathrm{Z}$ Douglas, The International Law of Investment Claims (2009) 148. See also G Fitzmaurice, The Law and Procedure of the International Court of Justice, vol II (1986) 438; J Paulsson, 'Jurisdiction and Admissibility', in G Aksen et al (ed), Global Reflections on International Law, Commerce and Dispute Resolution: Liber Amicorum in honour of Robert Briner (2005) 601, 617; J Collier \& V Lowe, The Settlement of Disputes in International Law: Institutions and Procedures (1999) 155; W W Park, Arbitration of International Business Disputes (2006) 77.

${ }^{29}$ Hochtief $v$ Argentina, ICSID Case No ARB/07/31 (Decision on Jurisdiction, 24 October 2011) para 90.

${ }^{30}$ See the claimants' arguments in Abaclat, above n 5, para 513(iii).

${ }^{31}$ Abaclat (Abi-Saab, diss, 28 October 2011), para 162.

32 S I Strong, 'Does Class Arbitration "Change the Nature” of Arbitration? Stolt-Nielsen, AT\& T and a Return to First Principles' (2012) 17 Harvard Negotiation LR 201, 251-2; Abaclat (Abi-Saab, diss, 28 October 2011), para 195.
} 
necessary to analyse whether initiating a mass claim against a party and adopting some procedural methods for that purpose require the approval of that party. The next three sections focus on different mechanisms of dispute settlement where the question of this kind of approval or consent arises. The purpose of these sections is to determine under what conditions such an approval is required and whether this requirement might be applied to mass claims by analogy.

\section{Mass claims and class arbitration}

The key difference between the judicial power of national courts and the jurisdiction of arbitral tribunals, for the dissenting arbitrator, was that the former 'stems from above, and not from the consent of the parties or litigants before them' and the latter 'from the consent of the parties.' ${ }^{33}$ This was the starting point for him to emphasise the role of consent in arbitration. He then relied upon the reasoning of the United States Supreme Court in two class arbitration cases, ${ }^{34}$ observing that consent to class arbitration or mass claims cannot be presumed from the parties' mere silence on the mass aspect of the arbitration. ${ }^{35}$ He grounded this opinion on three reasons: (i) 'the fundamental differences between the two modes of arbitration, the regular bilateral one and the class action or representative proceedings arbitration', (ii) 'the differences that "change the nature of arbitration"', and (iii) 'the great risks to which the later mode exposes defendants.' ${ }^{36}$

In order to test the accuracy of an analogy between class arbitration and investment mass claims, the US case law on class arbitration will first be examined. Born observed, "[o]ver the past two decades, the use of class action procedures migrated from litigation to arbitration in domestic U.S. practice. ${ }^{37}$ The debate at the Supreme Court level started with the Bazzle case. ${ }^{38}$ In this case, the Supreme Court adopted a rather liberal approach and left the determination of whether an arbitration agreement forbids class arbitration to

\footnotetext{
33 Abaclat (Abi-Saab, diss, 28 October 2011), para 147.

${ }^{34}$ Ibid, paras 148-53.

35 Ibid, para 151.

${ }^{36}$ Ibid, para 153

${ }^{37}$ G Born, 'The US Supreme Court and Class Arbitration: A Tragedy of Errors', Kluwer Arbitration Blog, 1 July 2011, <http://kluwerarbitrationblog.com/blog/2011/07/01/the-u-s-supreme-courtand-class-arbitration-a-tragedy-of-errors $>$ [accessed 28 June 2013].

${ }^{38}$ Green Tree Financial Corp v Bazzle, 539 US 444 (2003).
} 
the arbitrators. ${ }^{39}$ Hanotiau asserted that it can no longer be disputed that when the arbitration clause is silent on class actions, it is for the arbitrator to decide whether it authorises or prohibits classwide arbitration. ${ }^{40}$ In the past few years, the Supreme Court shifted its approach dramatically, ${ }^{41}$ issuing 'a series of confusing and, at times, confused opinions on class arbitration. ${ }^{42}$ In Stolt Nielsen $v$ AnimalFeeds, the Supreme Court considered that 'class action arbitration changes the nature of arbitration to such a degree that it cannot be presumed that the parties consented to it by simply agreeing to submit their dispute to an arbitrator. ${ }^{43}$ It further noted that in the absence of express consent to class arbitration or a default procedural rule in this line, the arbitral tribunal exceeded its powers by imposing its own policy choice. ${ }^{44}$ It identified the question as 'whether the parties agreed to authorize class arbitration' and held, consequently, that "where the parties stipulated that there was "no agreement" on this question, it follows that the parties cannot be compelled to submit their dispute to class arbitration.45 One of the leading American arbitrators, Park, remarks that the Supreme Court 'did not say [in this case] that parties must agree explicitly to class arbitration, but simply that the case at bar implicated no agreement, whether explicit or implicit'. ${ }^{46}$ Similarly, Beess und Chrostin is of the opinion that 'the Court in Stolt-Nielsen seems to wish to expressly leave open the window for class arbitration even where the contract does not explicitly provide for this procedure, so long as there are other factors or circumstances indicating that the parties intended to make the class arbitration mechanism available. ${ }^{47}$ One year later the political tension reappeared between the American conservatives who 'tend to favour arbitration as a process in line with freedom of contract', but whose 'preferences get reversed for class proceedings, which appear as an anti-business tool of plaintiffs' lawyers fomenting litigation on a contingency fee basis', and the liberal justices, who 'often express skepticism of arbitration as a device to

\footnotetext{
${ }^{39}$ Ibid, 451.

${ }^{40}$ B Hanotiau, Complex Arbitrations: Multiparty, Multicontract, Multi-issue and Class Actions (2005) 273.

${ }^{41}$ Born, above $\mathrm{n} 37$.

${ }^{42}$ G Born \& C Salas, 'The United States Supreme Court and Class Arbitration: A Tragedy of Errors' (2012) J Disp Resol 21, 21.

${ }^{43}$ Stolt-Nielsen SA v AnimalFeeds International Corp, 559 US (2010) 21.

${ }^{44}$ Ibid, $9,12$.

${ }^{45} \mathrm{Ibid}, 23$.

${ }^{46}$ W W Park, 'Arbitration in Autumn' (2011) 2 JIDS 287, 296.

${ }^{47} \mathrm{~J}$ Beess und Chrostin, 'Collective Redress and Class Arbitration in Europe: Where We Are and How To Move Forward' (2011) 14 Int ALR 111, 114.
} 
sidestep the perceived safeguards of a civil jury', but who, on the other hand, 'seem to perceive class proceedings as a pro-consumer mechanism permitting multiple litigants to engage jointly a legal team, making pursuit of the claims feasible. ${ }^{48}$ The Supreme Court confirmed its approach from Stolt-Nielsen in AT\&T v Concepcion. ${ }^{49}$

The Supreme Court's analysis in arriving at this conclusion should, however, raise an eyebrow. The Supreme Court supported its conclusion concerning secondary consent (in the sense of the term explained above in Section 3) by referring to cases which highlight the requirement of primary consent in arbitration. ${ }^{50}$ The dissenting judges in $A T \mathcal{E} T$ also criticised this general reference to cases involving primary consent and noted that there is no meaningful precedent that might support the view of the majority in these two cases. ${ }^{51}$ In any case, there is nothing in the judgments that were referred to by the Supreme Court that contradicts the possibility of bringing a class arbitration, so long as each claimant party to the arbitration has been contractually bound by an arbitration clause with the opposing party (the respondent). The only remaining basis for the majority's judgment was that class arbitration changes the nature of arbitration, and hence one might not assume consent to class arbitration from simple consent to arbitration. However, in Shady Grove Ortopedic v Allstate, Justice Scalia, who gave the majority opinion in the Supreme Court, had already stated that 'rules allowing multiple claims' do not 'abridge defendants' rights; they alter only how the claims are processed' and 'like traditional joinder', class action 'leaves the parties' legal rights and duties intact and the rules of decision unchanged. ${ }^{52}$

While the US Supreme Court could not find any convincing argument to support its conclusion on the class arbitration cases and instead referred generally to the 'nature' of the arbitration, and while this decision has been heavily criticised by the international arbitration community ${ }^{53}$ and is seen as being more in line

\footnotetext{
${ }^{48}$ Park, above n 46, 297.

${ }^{49}$ See especially AT\&T Mobility LLC v Concepcion, 563 US (2011) 13, where the Court held, '[c]lasswide arbitration includes absent parties, necessitating additional and different procedures and involving higher stakes. Confidentiality becomes more difficult. And while it is theoretically possible to select an arbitrator with some expertise relevant to the class-certification question, arbitrators are not generally knowledgeable in the often-dominant procedural aspects of certification, such as the protection of absent parties'.

${ }^{50}$ See Stolt-Nielsen, 559 US 662 (2010) 19-20.

${ }^{51}$ AT\&T Mobility LLC $v$ Concepcion, 563 US (2011) (Breyer J, diss) 10.

${ }^{52}$ Shady Grove Ortopedic Associates, PA v Allstate Ins Co, 559 US (2010) (Scalia J) 13-14.

${ }^{53}$ See generally Born, above n 42. Gary Born has written elsewhere, "[r] eading the various opinions in Bazzle, Stolt-Nielsen and now Concepcion makes one wish that the US Supreme Court would
} 
with the political orientation of Supreme Court judges than with their legal views, ${ }^{54}$ reliance on these cases by an arbitrator in an investment treaty case raises doubts. Not only was the perception of the Supreme Court of the concept of 'arbitration' fundamentally incorrect in those cases, ${ }^{55}$ but each legal system also has its own unique rules and policies, especially on procedural issues. The debate regarding collective arbitration can hence not be transplanted directly from one jurisdiction to another, ${ }^{56}$ and it should not be transplanted at all from a particular jurisdiction to the international level without considering the common and different features of the mechanisms at hand. One should only consider whether an analogy could be made between class arbitration and mass investment claims after having examined the different characteristics of these two mechanisms.

Class action proceedings before courts or in arbitration have particular characteristics: it is not simply many claimants bringing a case together. In class action proceedings, one claimant represents the class. Even if the class needs to be determined precisely, one cannot know how many people will enter in the class at the time of the filing of the claim. In other words, a class action is not a claim by individual claimants, but by a well-determined, yet still abstract class. One of the main features of a class action is that there are 'unnamed' parties in a class. ${ }^{57}$ Because of this feature, class action is recognised as an exception to the principle that one is not bound by a judgment in personam in a litigation, in which he is not designated as a party. ${ }^{58}$

In mass investment claims, however, there is no abstract class; there are concrete individual claimants. Nor are these claimants represented by a class-leader. Waibel comments on this point that '[u]nlike in [...] class actions, a small group of representative bondholders would [...] not represent the interests of all bondholders. ${ }^{59}$ Since there is no class in mass claims, there is no problem of choosing a representative of the class. ${ }^{60}$ Another difference is that there are not any 'unnamed' parties in mass investment claims: all the claimants are identified at the

stop deciding arbitration cases for a while - preferably, a long while': Born, above n 37.

54 See Park, above n 46, 296.

${ }^{55}$ Born \& Salas, above n 42, 22, 33, 39.

${ }^{56}$ Strong, above $\mathrm{n} 13,496$.

${ }^{57}$ On class action, see R L Marcus, M H Redish \& E F Sherman, Civil Procedure: A Modern Approach (3rd edn, 2000) 285.

${ }^{58}$ Hansberry $v$ Lee, 311 US 32 (1940).

${ }^{59}$ Waibel, above n 7, 276.

${ }^{60}$ Cf M Dimsey, The Resolution of International Investment Disputes (2008) 214. 
time of filing the claim. ${ }^{61}$ The number of claimants is therefore definite, subject to change only because of withdrawals. These features (the claimants are definite and bring their case individually instead of a class representative representing the whole class) contrast with the characteristics of class action. In a mass claim, there will not be a discussion on defining the class and the fiduciary role of the class representative who must obey due process rules.

Even if the US Supreme Court decisions were convincing and even if it were acceptable for class action to change the nature of an arbitration, the analysis in the previous paragraphs suggests that the main particularities of class action that might change the nature of the arbitration do not occur in mass (investment) claims. The only common point between a class action and a mass claim is the voluminous number of people that are involved in the case. A commentator observes:

while the magnitude of a proceeding may constitute a hallmark of class arbitration, it is not a defining factor. [...] [T]he mere fact that a proceeding resolves a large number of individual claims or a large amount in dispute cannot be said to "change[ the nature" of the proceeding from arbitration to something else, since large-scale claims have been resolved in arbitration before. ${ }^{62}$

Born and Salas have similarly stated that 'enormous disputes have always been, and still are, decided in arbitration. ${ }^{, 63}$

In conclusion, an analysis of the differences between class arbitration and mass claims suggests that the three reasons supporting the dissenting arbitrator's opinion in Abaclat ${ }^{64}$ cannot hold. First, even if there might be 'fundamental' differences between classical bilateral arbitration and class arbitration, these differences emanate from the particularities of class action and do not exist in mass investment claims. Second, apart from the voluminous number of parties involved in the arbitration, no ground can be identified to support a change in the nature of arbitration. This argument should also fail because large-scale claims have been resolved in arbitration before, as pointed out by Born and Strong. Third, the 'great risks' that mass claims might cause are not in fact related to the

\footnotetext{
${ }^{61}$ See also A M Steingruber, 'Case Comment: Abaclat and Others v Argentine Republic: Consent in Large-scale Arbitration Proceedings' (2012) 27 ICSID Rev/FILJ 237, 240.

${ }^{62}$ Strong, above $\mathrm{n} 31,213$.

${ }^{63}$ Born \& Salas, above n 42, 41.

${ }^{64}$ See Abaclat (Abi-Saab, diss, 28 October 2011), para 153.
} 
mass aspect of the claim, but rather to the fact that a large-scale dispute will be resolved through arbitration. It is true that judicial review is much more limited in arbitration. However, this argument holds against neither class arbitration nor mass investment arbitration claims; it concerns arbitration generally. Parties who simply give primary consent to arbitration already accept this risk. There is no need for special consent or a waiver for the risks embedded generally in the arbitration process. If it is argued that dealing with a voluminous number of claimants creates more risks, one might again refer to Strong, who notes that 'it seems strange, if not disingenuous given existing precedent, to suggest now that arbitrators lack the competence to handle such matters. ${ }^{65}$ Indeed, class arbitration is not a new phenomenon in the US. All in all, the dissenting opinion gives no coherent reasons to support the conclusion that mass claims change the nature of arbitration to such a degree that it cannot be presumed that the parties consented to it by simply agreeing to submit their dispute to an arbitrator, to draw an analogy between class arbitration and mass investment claims, or to apply the outcome of the US Supreme Court cases on mass claims. The need for special consent in mass investment claims might, however, be justified by reasons other than an analogy with class arbitration. This article will now explore these potential other reasons.

\section{Mass investment claims and international mass claims processes}

After drawing on an analogy with class arbitration, the dissenting arbitrator in Abaclat examined mass claims processes in international law. ${ }^{66}$ The dissenting arbitrator pointed out that in all known international cases (barring the fiat of the Security Council) a special agreement is needed. ${ }^{67}$ His conclusion was again that 'a mere acceptance to arbitrate does not cover collective mass claims actions [...] and that a special or secondary consent is needed for such collective actions. ${ }^{6}{ }^{6}$

International mass claims processes are established to consider legal claims resulting from significant historical events and mostly constitute large-scale reparation programmes for victims of armed conflicts. ${ }^{69}$ They include interna-

\footnotetext{
${ }^{65}$ Strong, above n 31, 263-4.

${ }^{66}$ See Abaclat (Abi-Saab, diss, 28 October 2011), paras 176-93.

${ }^{67}$ Ibid, para 185.

${ }^{68}$ Ibid, para 190.

69 'Mass Claims Processes', Permanent Court of Arbitration <http://www.pca-cpa.org/showpa
} 
tional claims commissions or tribunals where claimants can submit claims following the creation of a special mechanism, such as the Claims Resolution Tribunal, the United Nations Compensation Commission, the Iran-US Claims Tribunal or the Eritrea-Ethiopia Claims Commission. The establishment of such a mechanism requires the consent of the states that are involved in the disputes (unless the establishment of the mechanism is based on a Security Council mandate, which is the case for the United Nations Compensation Commission) as well as their participation.

An important characteristic of international mass claims processes is that the way claims are brought before the international commission or tribunal is not collective. Instead individuals bring their claims separately. Even in some international mass claims processes, such as the Iran-US Claims Tribunal, the tribunal treats each claim separately and conducts a case-by-case arbitration. ${ }^{70}$ In other words, some international mass claims processes provide merely a fast but individualised proceeding for each claim or group of claims, ${ }^{71}$ which results in a separate award or decision. ${ }^{72}$ Some other international mass processes, depending on the degree of commonality between the cases, might offer collective resolution of claims. ${ }^{73}$

The current President of the Iran-US Claims Tribunal, who is also the former President of the Eritrea-Ethiopia Claims Commission, has observed that 'Abaclat is not a mass claims process in the "traditional" sense. ${ }^{74}$ He defined a traditional mass claims process not only with reference to the plurality of claims enjoying some commonality of legal and factual issues, but also, more importantly, as a process where claims are decided individually. ${ }^{75}$

Indeed, investment treaty claims, including mass investment claims, have different characteristics. An investment tribunal does not 'receive' claims. It

ge.asp?pag_id=1059> [accessed 28 June 2013]. See also F Rosenfeld, 'Mass Claims in International Law' (2013) 4 JIDS 159, 159.

${ }^{70}$ See, for instance, J R Crook, 'Mass Claims Processes: Lessons Learned Over Twenty-Five Years', in International Bureau of the Permanent Court of Arbitration (ed), Redressing Injustices Through Mass Claims Processes: Innovative Responses to Unique Challenges (2006) 41, 44.

${ }^{71}$ Cf H Das, 'The Concept of Mass Claims and the Specificity of Mass Claims Resolution', in International Bureau of the Permanent Court of Arbitration, above n 70, 3, 7.

${ }^{72}$ For each modern mechanism, see H M Holtzmann \& E Kristjánsdóttir (eds), International Mass Claims Processes: Legal and Practical Perspectives (2007). See also International Bureau of the Permanent Court of Arbitration (ed), Institutional and Procedural Aspects of Mass Claims Settlement Systems (2000).

${ }^{73}$ See Rosenfeld, above n 69, 162.

${ }^{74}$ Van Houtte \& McAsey, above n 12, 231.

${ }^{75}$ Ibid, 232. 
is constituted subsequent to the filing of the case by the claimant or claimants. Moreover, each investment tribunal resolves only a single case, whereas a claims tribunal is constituted to resolve a defined set of claims as separate cases. One of the main differences between 'mass' investment claims and international mass claims processes is that whereas the former resolves one case, the other is entitled to resolve a problem (or all the cases within the ambit of the same problem). ${ }^{76} \mathrm{On}$ the other hand, as emphasised by Van Houtte and McAsey, 'Abaclat is a proceeding with numerous Claimants in one claim, a proceeding that groups claims together and brings them before a forum which can hear a wide variety of claims. ${ }^{77}$ They therefore prefer to use the term 'large-scale litigation' to describe what this article calls an 'investment mass claim' in order to distinguish it from traditional mass

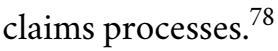

The existence of international mass process mechanisms established by special agreement should not automatically suggest that investment mass claims require special consent as well. A special agreement is necessary to establish a particular institution, so that all the claims within the same context can be brought to this mechanism. The special agreement does not purport to open the door to collective claims. On the contrary, it creates a body that can hear individual claims. Since there are many individual claims-and that is actually why claims commissions or tribunals are established-the filing of all those individual claims results in a mass claims process (but not a mass claim consolidated into a single case as has occurred in investment arbitration). But again, the reason behind the necessity of an agreement in case of the international mass claims processes is not to consent to collective claims, but rather to allow individual claims before a new and specific body.

All in all, mass investment claims are not comparable to international mass claims processes. An analogy between these two mechanisms can hardly be accomplished, due to the dissimilarities in the establishment of particular mechanisms and in the way these mechanisms treat cases. There is therefore no support in this international mechanism for or against the requirement of special consent to bring mass investment claims.

\footnotetext{
${ }^{76}$ See Crook, above n 70, 55.

77 Van Houtte \& McAsey, above n 12, 232.

${ }^{78}$ Ibid, 232. The reason this article prefers to use the adjective 'mass' instead of 'large-scale' is to distinguish the situation in Abaclat from other cases where many claimants are involved but not more than a handful, such as Ambiente Ufficio.
} 


\section{Mass investment claims as multi-party proceedings}

\subsection{Different types of multi-party proceedings and consolidation}

The Ambiente Ufficio tribunal described the claim at hand as a 'multi-party proceeding. ${ }^{79}$ As stated above, even if such qualification is legally accurate, it is not very helpful. The reason is that the term 'multi-party proceeding' might refer to any situation where there are more than two parties. For instance, whereas it is not clear that Ambiente Ufficio and Funnekotter are mass investment cases, they do involve multi-party proceedings. If one treats an investment claim initiated both by a mother company and a daughter company (or in any case, multiple claimants that are organically related) as a 'multi-party proceeding', one will find dozens of ICSID cases that involve multi-party proceedings. ${ }^{80}$ These are obviously not mass claims either. In respect of this kind of multi-party proceeding before ICSID tribunals, there is no real question of whether these proceedings are compatible with procedural rules of ICSID arbitration. For at least in this kind of multi-party arbitration, there is no need for specific consent on the part of the respondent beyond ordinary consent to refer the dispute to investment arbitration. ${ }^{81}$

The distinction between the types of multi-party proceedings is not limited to this. Consolidation or joinder is another mechanism that leads to multi-party arbitration. Consolidation allows several cases to be dealt with at once. ${ }^{82}$ Since the ICSID Convention and Arbitration Rules are silent on consolidation, it would be 'untenable to argue that the institution or the arbitration tribunal has the power to consolidate separate arbitrations' ${ }^{83}$ Such an ex post joinder or consolidation of proceedings would hence be subject to the specific consent (or rather agreement) of the parties. ${ }^{84}$ That was indeed the situation in Wintershall, where the Tribunal noted, 'an objection to the substitution of the Claimant by a new entity during the course of ICSID arbitration proceedings may be well-taken-for lack of empowerment of a Tribunal to do so, absent consent'. But, the respondent state

\footnotetext{
${ }^{79}$ Ambiente Ufficio, above n 11, para 122.

${ }^{80}$ Ibid, para 135.

${ }^{81}$ Ibid, para 146.

${ }^{82}$ Dimsey, above n 60, 125. See also G Kaufmann-Kohler et al, 'Consolidation of Proceedings in Investment Arbitration: How Can Multiple Proceedings Arising from the Same or Related Situations Be Handled Efficiently?' (2006) 21 ICSID Rev/FILJ 59, 65.

${ }^{83}$ Kaufmann-Kohler, above n 82, 91.

${ }^{84}$ Ambiente Ufficio (Decision on Jurisdiction and Admissibility, 8 February 2013) para 123.
} 
agreed to the joinder of the companies, and hence the tribunal found the power to continue the case with both companies as claimants. ${ }^{85}$

An original submission of a claim by a plurality of claimants in a single ICSID proceeding is not, however, a case of consolidation of proceedings. ${ }^{86}$ Mass investment claims, at least of the Abaclat type, do not involve the initial submission of a certain number of separate individual arbitrations which are subsequently consolidated and joined with each other; they have already been initiated as a single case. ${ }^{87}$ This difference between Abaclat-type mass claims and multi-party proceedings followed by consolidation explains why the requirement of consent for ex post joinder is not applicable in mass investment claims. An analogy should hence not be made between a consolidation proceeding and a mass claim with respect to the requirement of consent to the plurality of the claimants. ${ }^{88}$ In fact, a mass claim does not entail the problems that are attached to the consolidation of different cases initiated by different parties. Since the parties decide to initiate the case together, the problems that would be expected to arise in multi-party proceedings-related to the protection of confidential information, ${ }^{89}$ the full participation of the parties in the composition of the consolidated tribunal, and the consolidated parties' opportunity to present their case fully-would not occur.

This is obviously the case, so long as the claimants are represented uniformly and the flow of data towards the tribunal does not raise confidentiality issues among the claimants. This requires a high level of coordination among counsel for the claimants. That was achieved in Abaclat. One might point out that the claimants in that case were represented as if there were one single entity

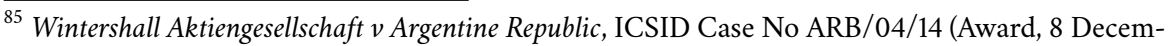
ber 2008) paras 59-60.

${ }^{86}$ Ambiente Ufficio, above n 11, para 124.

${ }^{87}$ The fact that Abaclat did not involve consolidation was also noted by the Ambiente Ufficio tribunal: Ambiente Ufficio, above n 11, para 124.

${ }^{88}$ But cf Manciaux, above $\mathrm{n} 10,311-13$. The consent required for an ex post consolidation process in investment arbitration cases underpins the commentator's conclusion that in the framework of ICSID arbitration consent to mass claims by the parties, especially respondent states, should be required: ibid, 313. He also criticises how the tribunal took no inspiration from 'neighbour procedures': ibid, 310 .

${ }^{89}$ Confidentiality may be an issue in multi-party investment cases, especially when the parties are marketplace competitors: C B Lamm, H T Pham \& A K Meise Bay, 'Consent and Due Process in Multiparty Investor-State Arbitrations', in C Binder et al (eds), International Investment Law for the 21st Century: Essays in Honour of Christoph Schreuer (2009) 54, 72. This is, however, not the case at least in Abaclat. Furthermore, unlike in international commercial arbitration, of which confidentiality is a cornerstone, the privacy of the proceedings is not a primary concern in investment arbitration: Schreuer, above n 1, 697; Strong, above n 13, 513. 
litigating against the respondent. As has been highlighted by Van Houtte and McAsey, it would have been very different if there had been no such cooperation (though it is factually very unlikely that many claimants represented by separate counsel will initiate a single investment claim) or if it had broken down in the middle of the proceedings. ${ }^{90}$ Indeed, should such a breakdown happen, the case might cease to be workable. That is, however, the case with any multi-party proceedings in investment arbitration and not only with mass investment claims. Would Funnekotter be workable, if there were a dozen different legal teams each submitting separate memorials recounting the facts inconsistently and based on clashing arguments, even if the claims enjoyed a high level of homogeneity? The likelihood of such a split should be considered bearing in mind that an important number of modern investment cases are brought by vulture funds, especially when the claim arises out of a relatively small- or medium-sized investment and where there is a single entity or a similar 'task force' that gathers the small-sized claims in order to bring a mass investment claim. In any event, the whole idea behind a mass investment claim is to share legal costs, including counsel fees, so that small-sized claims can be efficiently brought to investment arbitration. In case of a split, therefore, the case would not turn into a classical aggregate proceeding; instead some claimants would drop their claims, as in Abaclat (where around two-third of the claimants dropped their claims). The risk that Van Houtte and McAsey mention should not therefore be a reason not to admit mass investment claims where the representation of claimants is conducted uniformly or with a high level of coordination.

In conclusion, a mass investment claim is a multi-party proceeding. But not all multi-party proceedings entail secondary consent by the parties. That would be the case in a situation of consolidation; but Abaclat-type mass investment claims are very different from a consolidation process. The requirement of consent under consolidation hence cannot be applied to mass investment claims.

\subsection{Problems related to a mass multi-party proceeding}

The analysis above does not mean that the filing of a mass claim does not per se generate any problems. First, due to the enormous number of claimants compared with a classical case, an arbitral tribunal must adopt procedural arrangements in order to be able to administer the case properly. The question is thus whether an arbitral tribunal enjoys an inherent power to adopt such

${ }^{90}$ Van Houtte \& McAsey, above n 12, 232. 
arrangements on its own or whether it needs to be satisfied of the consent of the parties before doing so. The second and probably the more important concern relates to the ability of an arbitral tribunal to administer such a case involving a voluminous number of claimants with due respect for the procedural rights of the parties.

\subsubsection{Power of the tribunal to adopt some procedural arrangements}

It is indispensable for an investment tribunal to make some procedural arrangements in order to cope with a mass claim. Even the majority in the Abaclat tribunal did not deny this. But the question is to what extent a tribunal has power and discretion to adopt such procedural arrangements. The same question could be put in another manner: whether the way the Abaclat tribunal suggested conducting the case entailed a modification of the procedural rules of ICSID arbitration which required the consent (or approval) of the parties.

There are two important provisions under the ICSID mechanism that shed light on this problem. The first provision is Article 44 of the ICSID Convention, which reads:

Any arbitration proceeding shall be conducted in accordance with the provisions of this Section and, except as the parties otherwise agree, in accordance with the Arbitration Rules in effect on the date on which the parties consented to arbitration. If any question of procedure arises which is not covered by this Section or the Arbitration Rules or any rules agreed by the parties, the Tribunal shall decide the question.

The other provision is Rule 19 of the Arbitration Rules, which reads, " $t$ ]he Tribunal shall make the orders required for the conduct of the proceeding. Interpreting these provisions, the majority in Abaclat observed, 'the power of a tribunal is limited to the filling of gaps left by the ICSID Convention and the Arbitration Rules.' ${ }^{91}$ Manciaux confirms in his yearly comment on ICSID cases that the system under the ICSID Convention does not leave any place for improvisation by an arbitral tribunal. ${ }^{92}$

\footnotetext{
91 Abaclat, above n 5, para 522.

${ }^{92}$ Manciaux, above n 10, 307.
} 
The dissenting arbitrator, who examined the issue from the perspective of a third layer of consent (or tertiary consent) which bears on rules of procedure, ${ }^{93}$ considered the rules that should be adopted in Abaclat to be an implementation of a whole set of rules regarding mass claims, and not simply rules 'filling a gap. ${ }^{94} \mathrm{He}$ asserted that the procedural arrangements that the tribunal planned to make (the manner in which the tribunal would conduct the examination of the claims and the conduct of the proceedings) covered the usual subject of rules of procedure. ${ }^{95}$ In the dissenting arbitrator's opinion, the specific rules designed by the majority should thus be conceived as a modification of or a divergence from the existing rules of procedure. ${ }^{96}$ Characterising these rules as an adaptation would be simply playing on words. ${ }^{97}$ Since the dissenting arbitrator treated the 'specific rules' of the majority as a modification of the procedural rules, he argued that the tribunal should have required the consent of the parties before implementing these rules. He highlighted the importance of abiding by the existing procedural rules, asserting:

Procedural rights, the same as substantive rights, are not at the disposal and the discretion of the Tribunal. [...] [T] he majority award has unlawfully curtailed the Respondent's defense rights and thus flagrantly violated the due process arbitral standards [emphasis added]. ${ }^{98}$

Whether the procedural arrangement foreseen by the Abaclat tribunal consist of filling gaps or implementing a whole set of rules is a matter of interpretation. Unfortunately, there is not much material to shed light on the question, not much case law to act as guide and no generally accepted test to apply.

But one might compare the situation with a hypothetical class arbitration proceeding, as opposed to a mass claim. A class action procedure in investment arbitration would require the adoption of a whole set of rules regarding complicated procedural issues that would need to be clarified, such as the determination of the class, 'certification', notice to other class members, opt-in or opt-out options, the res judicata effect of the decision or the award to all the class members,

\footnotetext{
${ }_{93}$ Abaclat (Abi-Saab, diss, 28 October 2011), para 195.

${ }^{94}$ Ibid, para 202.

${ }^{95}$ Ibid, paras 211, 222.

${ }^{96}$ Ibid, para 213.

${ }^{97}$ Ibid, paras 216-17.

${ }^{98}$ Ibid, para 244.
} 
and the duties of the representative party. ${ }^{99}$ Mass claims are not comparable. ${ }^{100}$ Such problems do not arise in mass proceedings.

On the other hand, they do involve a more important issue: respect for the general procedural rights of the parties. Due process rights of the parties in a mass claim should be taken into consideration in the specific circumstances of the case. Since the way the claims of different claimants are bound to each other might be dissimilar in each case, it may not be possible to regulate due process concerns in relation to mass claims. As there is no other issue that needs to be regulated in respect of mass claims, tribunals should be left to find case-by-case solutions to this concern. That was the method adopted by the Abaclat tribunal and indeed is the only method for dealing with the mass investment claims. The Abaclat tribunal did not suggest adopting a whole set of rules in relation to mass claims, but rather decided to make relevant arrangements to cope with the case. ${ }^{101}$

More importantly, one should distinguish between the modification of procedural rules and the adoption of a method through procedural orders in order to be able to conduct the proceedings. In the second situation, a tribunal will not modify the procedural rules but will apply them in a way that facilitates the handling of the case. An oversimplified example is an ICSID claim initiated by two claimants (of which there are many examples in the dockets of the Centre). The fact that the procedural rules do not envisage that a claim might be initiated by two parties does not mean that a tribunal will modify the procedural rules when it analyses the jurisdiction ratione personae first for one party and then for the other. The tribunal will just adopt a method to deal with a particular problem. Procedural rules are not required to describe exhaustively every exercise of a tribunal's case-management rulings during a case. This 'power' involves the conduct of the proceedings. Rule 19 gives a certain discretion to arbitral tribunals on this issue. This discretion should cover the methods and procedural orders that the tribunal will use in order to cope with the case.

The procedural arrangement suggested by the majority of the tribunal (called by the majority an 'adaptation' and by the dissenting arbitrator 'specific rules') concerned the verification of evidentiary material. The majority proposed to implement a group treatment to simplify the flow and analysis of data. The simplification of the procedure would not, however, apply to the conduct

\footnotetext{
${ }^{99}$ See Rule 23 of US Federal Rules of Civil Procedure (as amended to 1 December 2010), on class actions.

${ }^{100}$ Compare the case at hand with the problems of a potential investment arbitration case initiated as a class action that are revealed by Dimsey, above $\mathrm{n} 60,213$.

${ }^{101}$ Abaclat (Procedural Order No 12, 7 July 2012).
} 
by Argentina that allegedly constituted a violation of the investment treaty undertakings. As an example of the evidentiary material that would be concerned, the tribunal suggested that it might accept scanned copies of an identification document instead of an original. ${ }^{102}$ Donovan, on the other hand, suggested that the Abaclat tribunal could have, for instance, used computerised data management that would, in his opinion, be unlikely to raise issues of procedural fairness or excess of authority. ${ }^{103}$ Accepting a scanned copy of a particular document instead of the original or adopting a particular method to manage relevant data do not amount to a modification of or a divergence from the procedural rules. Any tribunal could adopt such methods so long as the use of the special technique did not infringe one of the parties' positions (for instance, if forgery is an issue, scanned versions of identification documents might not be acceptable). Simplification of the evidentiary material is not directly related to the mass claim either. In a complicated bipartite dispute, a tribunal might need to simplify the analysis of documents that are of the same kind. All of these arrangements are about the conduct of the proceedings and do not involve filling the gaps of procedural rules, let alone modifying them.

In any case, the silence of the parties should not be construed as a hurdle to adopting a procedural arrangement, so long as the power 'aim[s] at regulating the proceedings, or [is] instrumental in the adjudication of the main claim, or [is] designed to safeguard the judicial character of courts.' ${ }^{104}$ Making the necessary adaptations is among the inherent powers of the tribunal. Indeed, international courts may also exercise other powers than those expressly conferred to them. ${ }^{105}$

\subsubsection{Due process concerns because of the mass aspect of the claim}

The second concern behind a mass investment claim is whether an arbitral tribunal is able to administer such a big case that involves many claimants. Managing this case might require comprising some general procedural guarantees that would apply to classical bilateral disputes. ${ }^{106}$ For instance, the Abaclat tribunal

\footnotetext{
${ }^{102}$ Abaclat, above n 5, para 531.

${ }^{103}$ D F Donovan, 'Case Comment: Abaclat and others v Argentine Republic As a Collective Claims Proceeding' (2012) 27 ICSID Rev/FILJ 261, 262-3.

${ }^{104} \mathrm{P}$ Gaeta, 'Inherent Powers of International Courts and Tribunals', in Lal Chand Vohrah et al (eds), Man's Inhumanity to Man: Essays on International Law in Honour of Antonio Cassese (2003) 353, 368.

${ }^{105} \mathrm{C}$ Brown, A Common Law of International Adjudication (2007) 60.

${ }^{106}$ Cf Rosenfeld, above n 69, 163-5. The author provides techniques used in connection with the establishment of facts in mass claims regarding the burden of proof, the standard of proof and the validation of information. These techniques depart from the general procedural rules.
} 
did not deny that "iit] will not be in a position to examine all elements and related documents in the same way as if there were only a handful of Claimants'. It signalled that it would implement mechanisms allowing a simplified verification of evidentiary material and that it would treat claimants in groups. ${ }^{107}$ This has been taken by the dissenting arbitrator as a violation of the procedural rights of the respondent. ${ }^{108}$ He noted, 'it is an absolute due process right of a respondent in a judicial or arbitral proceeding, to have every element of the claim or claims presented against him, examined by the tribunal, through adversarial debate that affords him full opportunity to contest and refute these elements one by one, if he can'. 109

Whereas the dissenting arbitrator is definitely right in his determination of the scope of the due process rights, his concern regarding the simplified mechanism to verify evidentiary material raises several questions.

First, even the dissenting arbitrator recognised that if this were a class action case or if the claims were identical, examining one claim would equate to examining all the claims and hence the tribunal [could] examine adversarially all the aspects and components of this one claim, in spite of the multitude of the claimants, totally safeguarding the due process rights of the respondent.'110 He also acknowledged that each claimant's claim shared common features and that they arose out of the same fact pattern. ${ }^{111}$ It is true that the claims were not identical: the claimants held different amounts of different bonds and security entitlements that were governed by different laws. But this does not change the character of the dispute. The substantive and jurisdictional analysis for establishing the investment treaty case is almost identical and thus need not be elaborated individually for each claimant. As emphasised by the tribunal, the measures taken by the respondent state affected the claimants in the same way. ${ }^{112}$ The majority of the tribunal also justified the group treatment and the simplification of the examination method by the homogeneity of the claims. ${ }^{113}$ The multiplicity of claimants would therefore have a minor impact-if not

\footnotetext{
The unconscious use of these techniques might result in exceeding the limits of the minimum procedural guarantee that one might expect and hence violate a party's due process rights.

${ }^{107}$ Abaclat, above n 5, paras 531, 536.

${ }^{108}$ Abaclat (Abi-Saab, diss, 28 October 2011), para 239.

${ }^{109}$ Ibid, para 236.

${ }^{110}$ Ibid, para 237.

${ }^{111}$ Ibid, para 238.

${ }^{112}$ Abaclat, above n 5, para 543.

${ }^{113}$ Ibid, paras 540-4.
} 
none-on the tribunal's assessment in the proceedings. ${ }^{114}$ The tribunal should still apply this technique with care. As noted by Donovan, if it were too aggressive in simplifying the examination method of the evidence, it might infringe on the procedural guarantees that the respondent is entitled to. Yet the tribunal can still conduct a sufficiently rigorous examination. ${ }^{115}$

Second, assuming that instead of claimants who individually and separately own investments, a company established by these individuals had conducted an investment, the case would be just as complex as in the actual situation but the claim would not be a mass claim. Since it would not be a mass claim, no one could have raised the argument that the tribunal needed special consent. Yet the same procedural problems would ensue. The complexity of the case would have required the tribunal to adapt procedural rules, and it would have again opted for a simplified procedure to assess the evidence. Rejection of such a claim due to the requirement of procedural adaptation and the simplified procedure to assess the evidence would raise the question whether investment tribunals have jurisdiction for complicated cases and whether such cases should be admissible. Such an outcome would not only be absurd, it would also be dangerous for the investment protection regime established by the ICSID Convention and by the network of bilateral and multilateral investment treaties. It cannot be forgotten that even in bipartite disputes with a huge pile of documents, it is counsel's job to bring to light the most important documents that will affect the outcome. ${ }^{116}$

\section{Conclusion}

The conclusion reached in this article should not be perceived as a consequence of a one-sided interpretation of the investment protection regime. The dissenting arbitrator's criticisms of that aspect of the majority's decision are legitimate. ${ }^{117}$ It is true that investment treaties and the ICSID Convention neither aim at protecting investments unilaterally ${ }^{118}$ nor afford absolute protection to foreign

${ }^{114}$ Cf Ambiente Ufficio, above n 11, paras 167, 170. But the case did not involve as many claimants as in a mass claim, and the tribunal expressly stated that Ambiente Ufficio was not a mass claim: ibid, 119-20, 171.

${ }^{115}$ Donovan, above $\mathrm{n} 103,267$.

${ }^{116}$ See also Strong, above n 13, 544; S I Strong, 'Enforcing Class Arbitration in the International Sphere: Due Process and Public Policy Concerns' (2008) 30 U Pa JIL 1, 91.

${ }^{117}$ See Abaclat (Abi-Saab, diss, 28 October 2011), paras 157-9, 260.

${ }^{118}$ See Report of the Executive Directors on ICSID Convention, paras 9ff, esp para 13. See also C McLachlan, L Shore \& M Weiniger, International Investment Arbitration: Substantive Principles 
investors. ${ }^{119}$ A tribunal hence should not justify whether a certain dispute falls within the scope of ICSID protection simply by the spirit of the Convention. Otherwise 'all the limitations to the jurisdiction of ICSID tribunals, whether inherent or patiently and carefully negotiated and stipulated in the treaty to protect the interests of the State party [would be] seen as obstacles in the way of achieving the "purpose" of the treaties', as was sensibly highlighted by the dissenting arbitrator. ${ }^{120}$ Indeed, the majority interpreted the silence as a permission to pursue the claim, which would conform with the purpose of the BIT and the spirit of the ICSID Convention. ${ }^{121}$ However, Article 31 of the 1969 Vienna Convention on the Law of Treaties would not allow the use of policy arguments to favour one of the parties by changing the proper meaning of the treaty under the guise of interpreting its object and purpose. In any case, "[o]ne of the objects and purposes will certainly be to maintain the balance of rights and obligations created by the treaty. ${ }^{122}$ One might, however, reach a similar conclusion following a technical analysis rather than a teleological one or a legal analysis based on economical efficiency considerations. ${ }^{123}$

The technical specificities of mass claims do not preclude the jurisdiction of an investment treaty tribunal to pursue the proceedings in the absence of special consent to the mass claim, because the fact that a case has been initiated by a multiplicity of claimants does not change per se the nature of the dispute. Mass claims are different in that sense from class action proceedings. Apart from a potential similarity in the number of claimants, the claimants in an investment mass claim do not constitute a 'class' and do initiate the case jointly. This divergence makes class action a very different procedural mechanism.

Moreover, an investment mass claim does not constitute an example to international mass claims processes that are established following the consent of the states involved in the dispute in order to settle a defined set of claims resulting from significant historical events. The consent of relevant states in mass claims processes relates to the creation of the dispute settlement institution rather than

(2007) 21; Manciaux, above n 10, 310.

${ }^{119}$ The protests against globalisation had the effect of bringing some changes to investment treaties, especially regarding environmental concerns, human rights, economic development, international concerns and the regulatory space of the host state: M Sornarajah, The International Law on Foreign Investment (3rd edn, 2010), 224.

${ }^{120}$ Abaclat (Abi-Saab, diss, 28 October 2011), para 158.

${ }^{121}$ See Abaclat, above n 5, para 519.

${ }^{122}$ M E Villiger, Commentary on the 1969 Vienna Convention on the Law of Treaties (2009) 427.

${ }^{123}$ For an analysis of Abaclat based on economic principles, see Rosenfeld, above n 69, 174. 
to the filing of the claims. Moreover, each claimant brings its claim before the tribunal or commission; claimants do not collectively initiate one single case.

Mass investment claims are technically multi-party arbitration proceedings. Still, one should distinguish different types of multi-party proceedings. Mass investment claims do not involve an ex post consolidation procedure. They have already been initiated by a multiplicity of claimants as a single case. Mass claims might entail an adaptation of procedural rules in order to let the tribunal manage the case. This adaptation-obviously depending on the particularities of the dispute, but at least in a case like Abaclat-does not demand a new set of rules. It should therefore not be construed as a change of procedural rules that require the agreement of the parties. Finally, it is true that facing a mass claim will deprive the respondent of the ability to examine all the evidence in detail. This will not, however, necessarily violate the due process rights of the respondent. A simplification of the procedure in assessing the evidence might be applied in mass claims, since there is a degree of identity between the claims of each claimant.

In conclusion, mass claims do not change the nature of arbitration. They are simply an effective procedural tool for conducting collectively claims enjoying a certain level of homogeneity. An investment treaty tribunal therefore need not be given special consent in order to hear a mass claim. The situation is thus no different from that in other multi-party investment claims. One can still leave aside those cases where each claim does not enjoy a certain level of homogeneity, or where the way the case has been brought would not be manageable under the current procedural rules, or even where the case is not factually workable at all (for instance, due to the non-uniform representation of claimants by different counsel). In those cases, either an investment tribunal will need to adopt a new set of procedural rules, which requires the agreement of the parties, or it will not be able to resolve the case while respecting the due process rights of the parties, which will make the claims inadmissible. In the latter case, an investment tribunal should reject the claim due to its inadmissibility, even if the parties give their approval or consent to the issue that would trigger the violation of due process rights of the parties or to a procedural tool that would be incompatible with the ICSID system. ${ }^{124}$

${ }^{124}$ Cf Manciaux, above n 10, 308. 